\title{
Uniaxial Elongational Viscosities of Ethylene lonomer / Styrene-co-Methacrylic Acid Blends
}

\author{
Akihiro NiSHIOKA*, Mihoko NishIO, Masataka SugIMOTO, \\ Tatsuhiro TAKAHASHI, Tomonori KoDA, Susumu IKEDA, \\ and Kiyohito KOYAMA \\ Department of Polymer Science and Engineering, \\ Yamagata University, Yonezawa 992-8510, Japan
}

\begin{abstract}
The effects of non-neutralized carboxylic acid(-COOH) on strain hardening of EMAA-54Na and EMAA-59Zn ionomers blended with StMAA and PS were investigated. In case of EMAA-54Na/StMAA blend, unexpected strong strain hardening appeared. However, this tendency was not found to all other samples. It was considered that cause of unexpected phenomena of EMAA-54Na/StMAA blend came from strong interaction between EMAA-54Na and StMAA due to acid-cation exchange mechanism proposed by Vanhoorne et al. Further, it was considered that nonneutralized carboxylic acid(-COOH) was the new key to increase the intensity of strain hardening for EMAA-ionomers. Key Words: Ionomer / Elongational viscosity / Strain hardening / Blend
\end{abstract}

\section{エチレン系アイオノマーIスチレンーメタクリル酸 共重合体ブレンドの一軸伸長粘度特性}

西岡 昭博*, 西尾 美帆子, 杉本 昌隆, 高橋 辰宏, 香田 智則, 池田 進, 小山 清人

（原稿受理：2003年6月6日）

1. 緒言

エチレン系アイオノマーは, エチレンーメタクリル酸共重 合体（以下，EMAAと呼ぶ）のメタクリル酸部を金属イオン によりイオン化した高分子材料である. エチレン系アイオノ マーは，1960年に米国デュポン社がガラスのように透明で強 勒な熱可塑性樹脂というキャッチフレーズで,「Surlyn」の名 で発表した。この材料は高分子鎖間をイオン結合により疑似 架橋されている点に特徵がある. 工業的には, ナトリウム (Na) や亜鉛 $(\mathrm{Zn})$ 金属イオンによりイオン化 (以後, 中和 と呼ぶ）されたものが多く用いられる.

エチレン系アイオノマーは, ベースとなるポリマーと比較 し, 剛性, 反発弾性, 透明性などが著しく向上する.この優 れた特性を利用し，様々な分野の用途に用いられている.

従来より, エチレン系アイオノマーの固体物性に関する研 究は, 多くの研究者により行われてきた. ${ }^{1-8)}$ エチレン系アイ オノマーの固体構造は, デュポン社の研究者であるLongworth によりすでに提唱されている. ${ }^{9}$ Longworthによるモデルは, ポリエチレンの「結晶部」、「非結晶部」および金属イオンが 凝集した「イオン凝集部 (体)」の3相構造の存在を示してい

*Author to whom all correspondence should be addressed.

Tel \& Fax : 81-238-26-3207

E-mail : nishioka@yz.yamagata-u.ac.jp
る.さらに，イオン凝集体は低中和度では発達しておらず, ある程度の高い中和度において形成される.イオン凝集力 は，一般に強く，そのためイオン凝集体の内部粘度は非常に 高くなる。これにより, 結晶形成が妨げられ, 微結晶が形成 される. 固体物性においては，イオン凝集体の存在が機械的 物性を向上させていることが多くの研究から確かめられて いる. 1),3-7), 10-12), 14-15) 最近では，平沢らにより，エチレン系アイ オノマーの機械物性を検討した結果, $\mathrm{Na}$ イオンにより中和さ れたアイオノマーは中和度 $33 \%$, Znイオンにより中和された アイオノマーでは中和度 $80 \%$ 付近にて，イオン凝集体が形成 されると報告している. 3,5$)$

一方, 溶融状態におけるエチレン系アイオノマーの研究は 固体における研究と比較し, 極端に少ない. 固体物性に大き な影響を与えるイオン凝集体は，約 $300^{\circ} \mathrm{C}$ 付近まで存在して いることが小角X線解析によりすでに明らかにされている. 9) 従ってイオン凝集体は, 溶融状態でも存在していることか ら, 溶融レオロジーに対してイオン凝集体が影響を及ぼすこ とは容易に想像できる.

このことを支持する特に興味深い研究として, Vanhoorneら が報告したAcid-Cation Exchange（酸一陽イオン交換）効果が

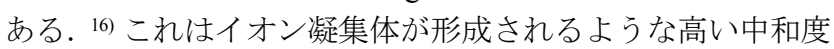
では, ベースポリマーの中和されていないカルボキシル基 (以後, 未中和のカルボン酸 : - $\mathrm{COOH}$ ) がイオン凝集体内の 
金属イオンに配位し，凝集体内部に入り込むことにより引き 起こされる. イオン凝集体内に入り込んだ未中和のカルボン 酸 (-COOH) はイオン凝集体内のイオン結合を解離させる. これにより, 溶融粘度が減少する。一般に, アイオノマーの 固体における機械物性は中和度が高いほど優れる。しかし， これに反して, 高い中和度では溶融粘度が高くなるために 成形時に支障が出てしまう。従って, アイオノマー樹脂の 性能を $100 \%$ 引き出すためには, 中和度を高く保った状態で 粘度を下げる技術が求められている. 著者らは, この点に 着目しアイオノマー樹脂に低分子量の酸であるモンタン酸 $\left(\mathrm{C}_{27} \mathrm{H}_{55} \mathrm{COOH}\right)$ をブレンドすることで, イオン凝集体内に低 分子量酸が配位結合力により入り込み, 凝集体内のイオン結 合を解離させることで, 溶融粘度を積極的に減少させられる ことを見い出した. ${ }^{17)} こ の$ 結果は, イオン凝集体と材料中の 未中和のカルボン酸には互いに強い相互作用があることを 示唆している．金属イオンにより中和されていないカルボン 酸（-COOH）がイオン結合やイオン凝集体に影響を与え, 溶 融レオロジーに大きく影響を及ぼす効果があることが分 かってきた。

そこで, NaおよびZn金属により中和されたエチレン系アイ オノマーに未中和のカルボン酸を含むポリマー (スチレンー メタクリル酸共重合体 (StMAA)) をブレンドすることを考え た. ブレンドされたStMAAはイオン凝集体に積極的に作用 し，レオロジー特性に影響を与えるのではないかと考えた. 本研究では, 特に一軸伸長粘度のひずみ硬化性に着目し, 未 中和のカルボン酸を含むStMAAをブレンドすることで, エチ レン系アイオノマーの一軸伸長粘度のひずみ硬化性に与える 未中和カルボン酸の効果を明らかにすることを目的とした.

また未中和のカルボン酸の存在が一軸伸長粘度へ与える 影響を明確にするため, 構造中に未中和のカルボン酸を含ま ないポリスチレン (PS) とのブレンド系も同時に比較対象と して検討した.

\section{2. 試料と実験}

\section{1 試料}

エチレン系アイオノマーは三井・デュポンポリケミカル社 製のものを用いた. ベースポリマーはエチレンーメタクリル 酸共重合体 (EMAA: $M \mathrm{w}=94,500, M \mathrm{w} / M \mathrm{n}=4.9$, MAA 含量: $5.4 \mathrm{~mol} \%$ ）である. 今回用いた試料は，上記のEMAAを Naお よびZn 金属イオンにより全体のカルボン酸の $54 \%$ および59 \%を中和したもの（以後EMAA-54NaおよびEMAA-59Znと呼 ぶ）である. ブレンドしたスチレンーメタクリル酸共重合体 (StMAA: $M \mathrm{w}=190,000, M \mathrm{w} / M \mathrm{n}=2.4$, MAA含量: $10.1 \mathrm{~mol} \%$ ) は A\&Mスチレン社製のものを用いた. 比較対象用として同社製 のポリスチレン（PS: $M \mathrm{w}=328,000, M \mathrm{w} / M \mathrm{n}=2.4 ）$ も同時に用意 した. 本論文において用いた全ての試料の分子量測定はGPC により行い, PS基準の測定結果である.

ブレンドは, 池貝製二軸混練機（型式 : PCM30 L/D=31.5） を用いて $200^{\circ} \mathrm{C} て ゙$ 行い, ペレット化した. ブレンド比は, EMAA-54NaおよびEMAA-59Znに対してStMAAまたはPSをそ れぞれ重量比で $75 \mathrm{wt} \%: 25 \mathrm{wt} \%$ とした. 全てのブレンド後の試 料は, 完全に白濁し, 非相溶であることを目視により確認 した.
試料は，測定前に水分の影響を完全に排除するため, $80^{\circ} \mathrm{C}$ で少なくとも 10 日以上減圧乾燥後に測定した. ${ }^{17-19)}$

\section{2 レオロジー測定}

動的せん断粘弾性測定および一軸伸長粘度測定を行った. 実験装置はレオメトリックス社製平行円盤型レオメータ ARESおよびマイスナー型一軸伸長レオメータRMEを用い た. 動的粘弾性測定は基準温度を $160^{\circ} \mathrm{C}$ と， $20^{\circ} \mathrm{C}$ おきに $220^{\circ} \mathrm{C}$ まで測定を行った。 全てに対し温度一時間換算則を適 応し, マスターカーブを作成した。動的測定の周波数範囲は $10^{-2} \sim 10^{2}(\mathrm{rad} / \mathrm{s})$ であり, 測定はすべて $\phi 25 \mathrm{~mm}$ のパラレルプレー トで行った.

一軸伸長粘度測定はすべて $160^{\circ} \mathrm{C} て ゙$ 行った。ひずみ速度は, 0.5 0.01/sの範囲で行った.

動的せん断および一軸伸長粘度測定のいずれの測定も，す ベて窒素䨌囲気下で行った。

サンプル形状は，せん断動的粘弾性測定は円柱状（直径 $\times$ 厚さ $=25 \mathrm{~mm} \times 2 \mathrm{~mm})$ とした。一軸伸長粘度測定は, 直方体と した（長さ $\times$ 幅 $\times$ 厚さ $=60 \mathrm{~mm} \times 7 \mathrm{~mm} \times 2 \mathrm{~mm}$ )。測定用試料は(侏東 洋精機製作所製のMINI-TEST-PRESS-10により，圧力 $15 \mathrm{MPa}$, 温度 $200^{\circ} \mathrm{C}$ で圧縮成形した。 その後, ただちに $15 \mathrm{MPa} の$ 加圧 下で急冷し，測定用試料を得た。

\section{3. 結果と考察}

\subsection{EMAA-54Na/StMAAおよびEMAA-54Na/ PS ブレンド}

Figure 1に, EMAA-54Na / StMAA (75:25wt\%)の動的粘弾性 測定結果を示す。 $160^{\circ} \mathrm{C}$ を基準温度とし， $20^{\circ} \mathrm{C}$ おきに测定を 行った。本実験の測定温度域である $220^{\circ} \mathrm{C}$ ま゙は温度一時間 換算則が成立した。測定範囲内において低周波数領域には, 材料中のドメイン（イオン凝集体やStMAA）の緩和に起因す るような $G^{\prime}$ の顕著な増大は特に見られなかった.このことは, 他の全ての試料においても同様に言えた.

Figure 2 にStMAA，PSの一軸伸長粘度を示す．またFig.3に EMAA-54Na，EMAA-54Na/StMAA とEAA-54Na/PSブレンド の一軸伸長粘度測定結果を示した。 どの試料においても, 線 形粘度はせん断粘度の 3 倍 $\left(3 \eta_{\mathrm{s}}(t)\right)$ にほぼ一致し, 全てにお

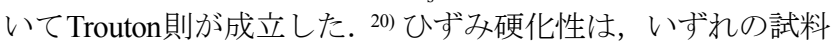
にも顕著に見られた．各試料のひずみ硬化の強さをサンプル

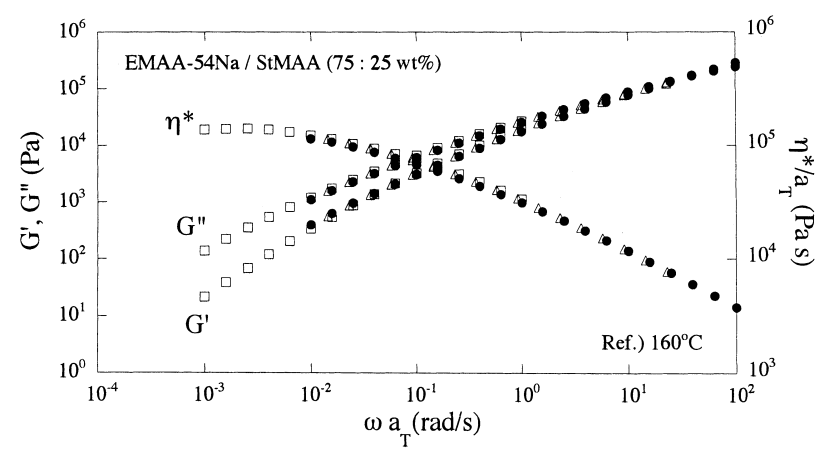

Fig.1 Master curve of $G^{\prime}, G^{\prime \prime}$ and $\eta^{*}$ for EMAA-54Na/StMAA blend. The reference temperature is $160^{\circ} \mathrm{C}$. 
間で定量的に比較する必要がある. 本研究では，小山らが提 案した以下の式を用いてひずみ硬化性を定量化し，試料間で の比較を行うことにした. ${ }^{21)}$

$$
\lambda \mathrm{n}=\eta_{\mathrm{E}}(t)_{\text {non-linear }} / \eta_{\mathrm{E}}(t)_{\text {linear }}
$$

ここで，式中の入nは非線形パラメータと呼び，線形粘度か らどの程度伸長粘度が離れているかを示す。 また， $\eta_{\mathrm{E}}(t)_{\text {linear }}$ お よび $\eta_{\mathrm{E}}(t)_{\text {non-linear }}$ はそれぞれ, ある時間 $\mathrm{t}$ における線形粘度およ び非線形粘度を示す。

EMAA-54Na, StMAA, PS, EMAA-54Na/StMAA, EMAA-54Na/ PSの計算結果をFig.4に示す. 図中の傾きはひずみ硬化の強さ を表す指標となる。

Figure 4において，EMAA-54Na/StMAAおよびEMAA-54Na/ PSブレンド系でひずみ硬化性をそれぞれ単体のそれと比較 した. EMAA-54Na/PS（Fig.4(a)）では, ひずみ硬化性の強さ (非線形パラメータの傾き) は, EMAA-54Na単体のそれより も弱くなっていることが分かる. 一方, EMAA-54Na/StMAA (Fig.4(b)）ではひずみ硬化の強さが, EMAA-54Naおよび StMAAの単体よりも明らかに強くなるという予想外の結果 を得た。

これより未中和のカルボン酸を含むStMAAをEMAA-54Na にブレンドした際に予想外の顕著なひずみ硬化性の増大を 示すことが分かった。さらに未中和のカルボン酸を含まない PSではStMAAをブレンドした時のような顕著な増大は見ら れないという対照的な結果を得た。

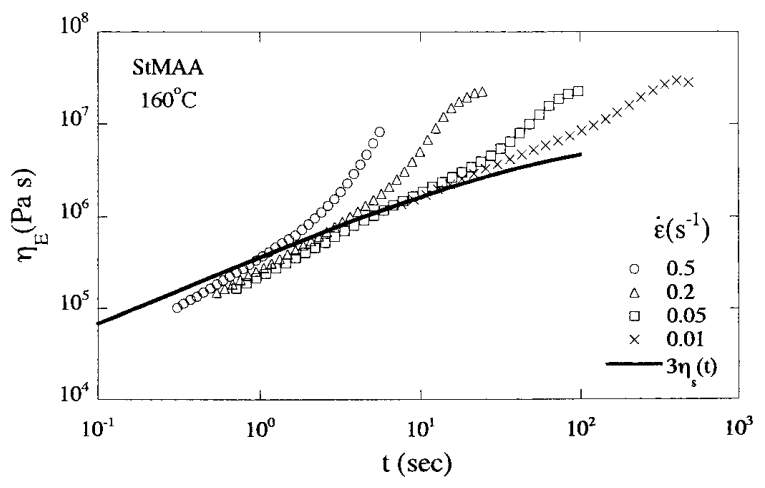

(a) StMAA

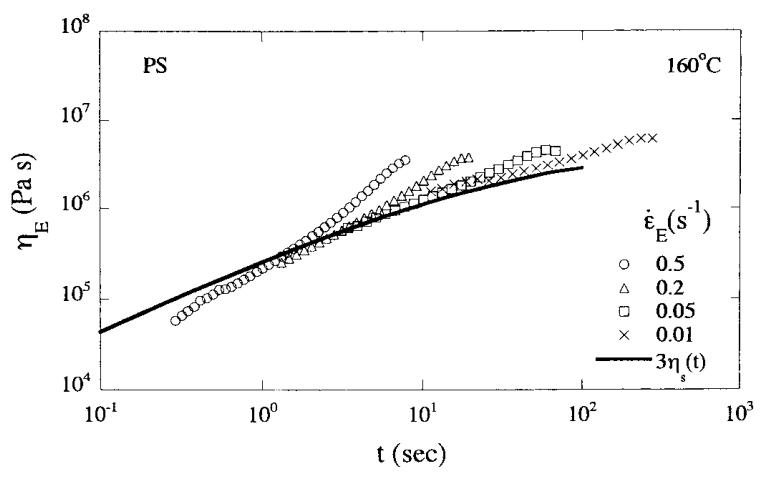

(b) PS

Fig.2 Uniaxial elongational viscosities for StMAA and PS at $160^{\circ} \mathrm{C}$.
3.2 EMAA-59Zn/StMAA および EMAA-59Zn/ PS ブレンド

いずれの系でも, 動的粘弾性測定の結果においてEMAA54Naブレンド系と同様な結果を得た.

Figure 5に, EMAA-59Zn, EMAA-59Zn/StMAA, EMAA-59Zn/ PSの一軸伸長粘度測定結果をそれぞれ示す。この系において も線形粘度域ではせん断粘度の3倍にほぼ一致し, Trouton則 に従った.さらに，すべての系においてひずみ硬化性が見ら れた. 3.1 と同様に, 式(1)より, 各試料のひずみ硬化パラメー 夕を算出し，その結果をFig.6に示した. 興味深いことに EMAA-59Znブレンド系では, EMAA-54Naブレンド系に見ら れたようなStMAAをブレンドした際の顕著なひずみ硬化の 増大は見られなかった。 さらに, EMAA-59Znブレンド系で は, ひずみ硬化に与えるブレンドの効果には, PS と StMAAと いったブレンドする材料の種類に依らないことも分かった. 以上のことから, StMAAをブレンドしたことによる顕著なひ ずみ硬化の増大は, EMAA-54Naブレンド系においてのみ引き 起こされる特徵的な現象であることが分かる.

\section{3 両ブレンド系の比較}

前節までに, EMAA-54Na/StMAA ではEMAA-54Naおよび StMAA単体に比べ, 強いひずみ硬化性が発現することが分 かった。この効果は，EMAA-54NaにPSのような構造中に未

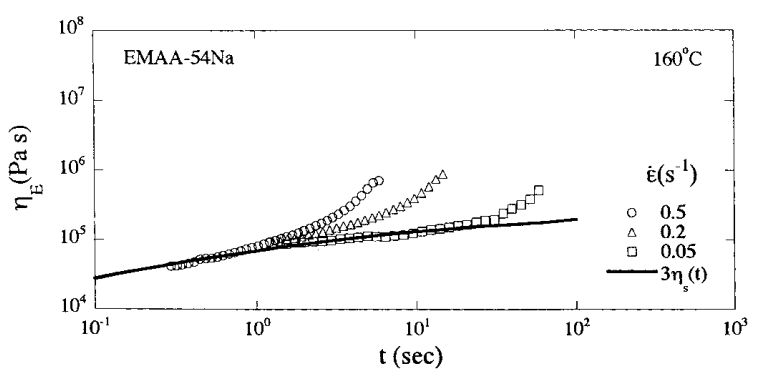

(a) EMAA-54Na

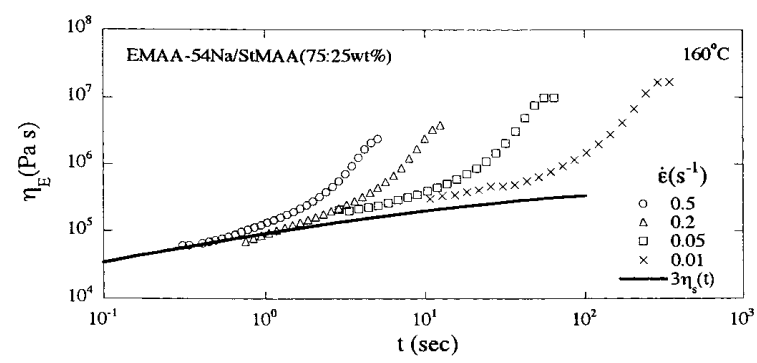

(b) EMAA-54Na / StMAA

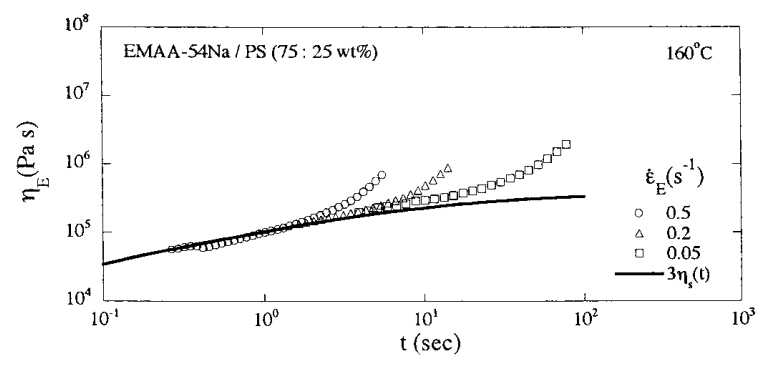

(c) EMAA-54Na / PS

Fig.3 Similar to Fig.2 for EMAA-54Na, EMAA-54Na/StMAA and EMAA-54Na/StMAA at $160^{\circ} \mathrm{C}$. 
中和のカルボン酸を含まないポリマーであるPSをEMAA54Naにブレンドしても発現しない. 一方, EMAA-59Znでは StMAA，PSのどちらをブレンドしても， EMAA-54Naブレン ド系のような強いひずみ硬化性は発現しない，構造中に未中 和のカルボン酸を含むStMAAをブレンドし, 特異なひずみ硬 化の増大を示すのは, EMAA-54Naのみである. 従ってEMAA$54 \mathrm{Na}$ でのみStMAA分子鎖中の未中和のカルボン酸が何らか の影響を及ぼしていると考えられる.

Na金属イオンにより中和されたアイオノマーにおいて, 未 中和のカルボン酸が溶融レオロジーに影響を及ぼすことを 明らかにした興味深い研究結果はVonhoorne らによってすで に報告されている。16)しかも, 未中和のカルボン酸が影響を 及ぼすのは, Naにより中和されたアイオノマーのみで, Znに より中和されたアイオノマーにおいては影響しないことも 同時に報告されている. この点において, 本研究の結果と非 常に良く一致している. Vanhoorneらは, アイオノマー中のイ オン凝集体内に未中和のカルボン酸が配位結合力により入 り込み, 凝集体内のイオン結合を解離させるという AcidCation-Exchange（酸一陽イオン交換）メカニズムを提唱した. この際，未中和のカルボン酸が，イオン凝集体内に入り込む ことが絶対条件である. Naのようなアルカリ金属やアルカリ 土類金属は6配位8面体構造をとることが知られている.この ことは金属イオン1価あたりに3個のカルボキシル基が配位す ることに相当する. 従って, $\mathrm{Na}$ のようなアルカリ金属やアル カリ土類金属系のアイオノマーではイオン凝集体を形成し ている金属イオンの周りに1価あたり常に2個の未中和カルボ

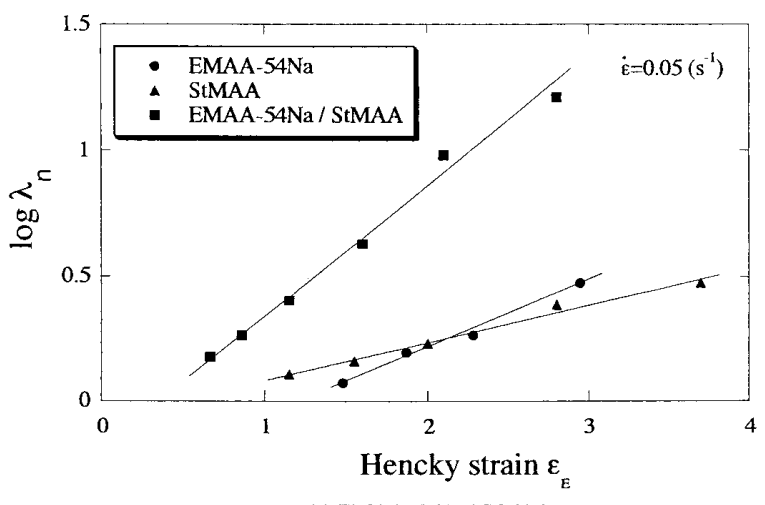

(a) EMAA-54Na / StMAA

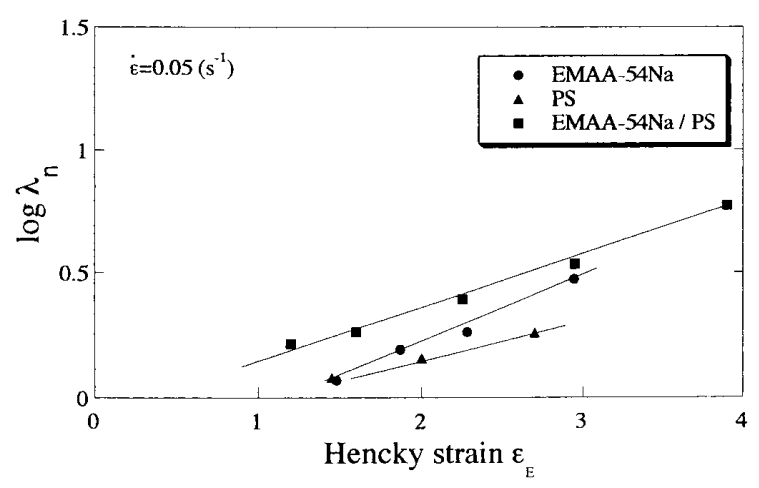

(b) EMAA-54Na / PS

Fig.4 Non-linear parameters for EMAA-Na blend system.
ン酸が存在することを意味する。 ${ }^{3)}$ 一方， Zn タイプのアイオ ノマーでは，普通4配位4面体型の配位構造を形成する。これ は Zn 金属 1 個あたり4個の酸素原子が配位できることを意味 するが，Zn金属は2価のイオンであることから，イオン結合 するカルボキシレート (-COO-) だけで，それ以外のものは 配位できない. 10-11), 22-24)

以上のことから, 本研究の結果を考えると，イオン凝集体 内に未中和カルボン酸が配位し，入り込める可能性があるの は，EMAA-54NaにStMAAをブレンドした時のみである。こ のことから判断すると, 未中和のカルボン酸を含むStMAAは EMAA-54Na中で独立して存在せず, イオン凝集体内にStMAA 分子鎖が入り込み, EMAA-54Na との間に強い相互作用を及ぼ していると考えられる. 当然の事ながら, EMAA-54Naに未中 和カルボン酸を持たないPSをブレンドした場合は，イオン凝 集体への影響はない，本研究におけるブレンド試料は，非相 溶系であると先に述べたが，実験結果から考えるとアイオノ マー中のイオン凝集体と StMAA 中の未中和のカルボン酸は 互いに相溶状態にあり，強い相互作用を及ぼしている考えら れる.

一方, Vanhoorneらの結果を考えると, EMAA-59ZnにStMAA やPSの違いに関係なく，いずれの材料も凝集体内に配位する ことはできない.このように考えると, StMAAやPSはEMAA$59 \mathrm{Zn}$ 中に独立して存在し互いに相互作用を及ぼしにくい. こ

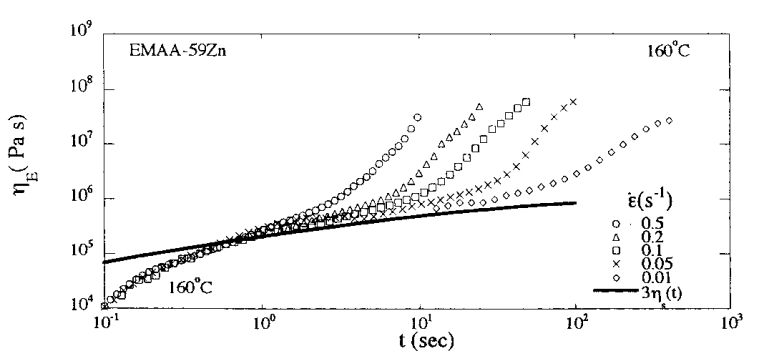

(a) EMAA-59Zn

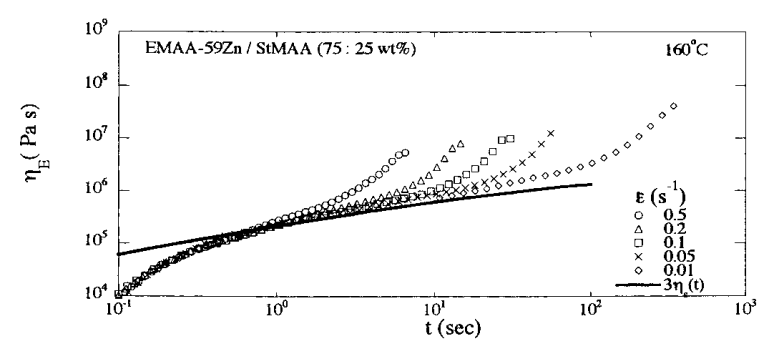

(b) EMAA-59Zn / StMAA

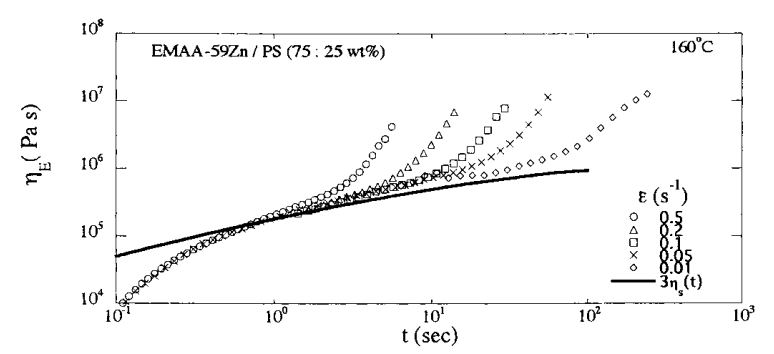

(c) EMAA-59Zn / PS

Fig.5 Similar to Fig.2 for EMAA-59Zn, EMAA-59Zn/StMAA and EMAA-59Zn/StMAA at $160^{\circ} \mathrm{C}$. 
のような考えに基づくと,ブレンドしたStMAAやPSはEMAA$59 \mathrm{Zn}$ の一軸伸長粘度を増大させるような効果がないという 実験結果に納得がいく.

\section{4. 結 論}

本研究では，エチレン系アイオノマーの一軸伸長粘度のひ ずみ硬化性に与える未中和カルボン酸の効果を検討した。そ の結果，以下のような知見を得た.

EMAA-Naアイオノマーに未中和のカルボン酸を含む StMAAをブレンドすることにより，イオン凝集体内の金属イ オンに StMAA分子鎖が配位し，EMAA-54Naアイオノマーと StMAA との間に強い相互作用が生じる.これにより，ブレン ド後に強いひずみ硬化性が発現したと考えた。さらに，この 効果は，PSのように構造中に未中和のカルボン酸 (-COOH) が存在しない場合は，起こらない.

一方，もともとイオン凝集体内に未中和カルボン酸が配位 できないEMAA-Znアイオノマーでは，StMAAやPSの種類を 問わず，ブレンド後のひずみ硬化の増大はない.

以上のことから，アイオノマー中のイオン凝集体に未中和 カルボン酸が配位出来る系でのみ，ブレンド後の強いひずみ 硬化性が発現することが分かる，具体的には，本研究におけ るStMAAのような未中和のカルボン酸を含む材料を, 未中和 のカルボン酸 (-COOH) がイオン凝集体内に配位できる $\mathrm{Na}$ 系 のアイオノマーにブレンドすることで，ひずみ硬化性の増大 が期待できる.

本研究による一連の結果は, アイオノマー樹脂のひずみ硬

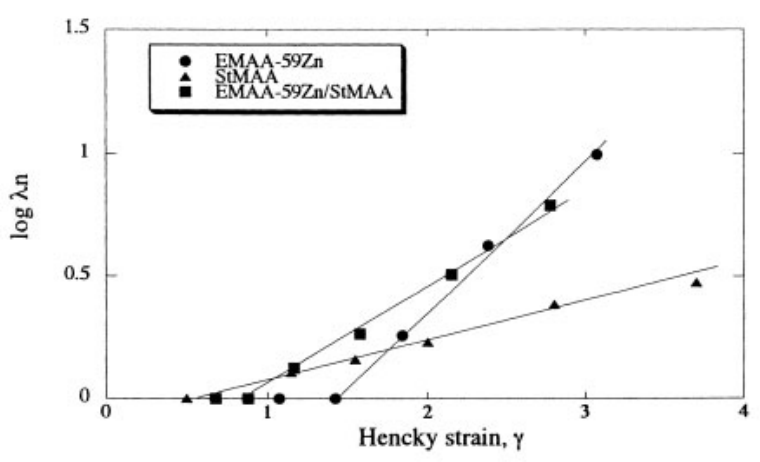

(a) EMAA-59Zn / StMAA

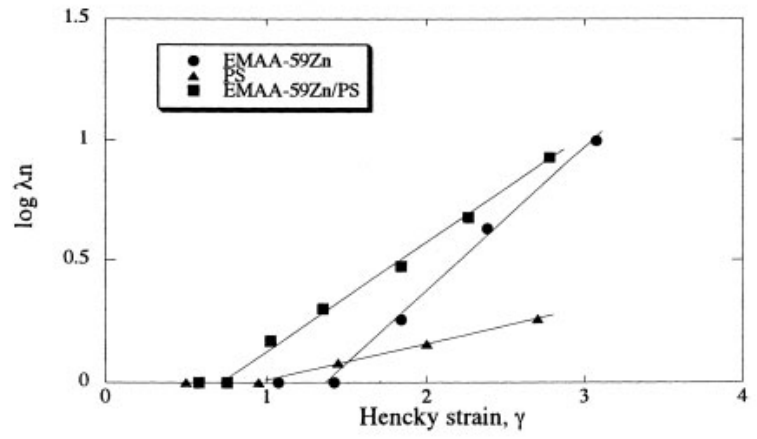

(b) EMAA-59Zn / PS

Fig.6 Similar to Fig.4 for EMAA-Zn blend system.
化性を増大させるための一つの可能性を提示していると考 えている.

\section{謝辞}

本研究において用いましたアイオノマー樹脂およびスチレ ン樹脂はそれぞれ三井・デュポンポリケミカル(株，A\&Mスチ レンより提供を頂きました。この場をお借りし，謝辞を申し 上げます，有益な議論を頂きました山形大学工学部の谷口貴 志博士に心よりお礼申し上げます。 なお，本研究は科学研究 費補助金第15300250号の援助を受けて行いました.

\section{REFERENCES}

1) Hirasawa E, Yamamoto $Y$, Tadano $K$, Yano $S$, Macromolecules, 22, 2776 (1989).

2) Hirasawa E, Kyoto University Doctor Thesis (1989).

3) Hirasawa E, Yamamoto Y, Tadano K, Yano S, J Appl Polym Sci, 42, 351 (1991).

4) Tachino H, Kyoto University Doctor Thesis (1994).

5) Tachino H, Hara H, Hirasawa E, Kutsumizu S, Tadano T, Yano S, Macromolecules, 26, 752 (1993).

6) Tachino H, Hara H, Hirasawa E, Kutsumizu S, Tadano T, Yano S, J Appl Polym Sci, 55, 131 (1995).

7) Tadano K, Hirasawa E, Yamamoto H, Yano S, Macromolecules, 22, 226 (1989).

8) Earnest T R, Macknight W J, L Polym Sci, 16, 143 (1978).

9) Longworth R, Morawetz H, J Polym Sci, Prag Symp, 29, 307 (1958).

10) Grady B P, Floyd J A , Genetti W B, Vanhoorne P, Register R A, Polymer, 40, 283 (1999).

11) Grady B P, Macromolecules, 32, 2983 (1999).

12) MacKnight W J, Earnest(Jr) T R, J Polym Sci, Macromol Rev, 16, 41 (1981).

13) MacKnight W J , Kajiyama T, McKenna L, Polym Eng Sci, 8, 267 (1968).

14) MacKnight W J, Mckenna L W, Read B E, Stein R S, J Phys Chem, 72(4), 1122 (1968).

15) Tachino H, Hara H, Hirasawa E, Kutsumizu S, Tadano K, Yano S, Macromolecules, 26, 752 (1993).

16) Vanhoorne P, Register R A, Macromolecules, 29, 598 (1996).

17) Nishioka A, Takahashi T, Masubuchi Y, Takimoto J, Koyama K, Polymer, 42, 7907 (2001).

18) Nishioka A, Takahashi T, Masubuchi $Y$, Takimoto J, Koyama K, J Rheology, 46(6), 1325 (2002).

19) Nishioka A, Yamagata University Doctor Thesis (2000).

20) Trouton F T, Proc Roy Soc, 77, 426 (1906).

21) Koyama K, Ishizuka O, Polym Proc Eng, 1(1), 55 (1983).

22) Coleman M M, Lee J Y, Painter P C, Macromolecules, 23, 2339 (1990).

23) Ishioka T, Polymer J, 25(11), 1147(1993).

24) Zeng X, Yamane H, Takahashi M, Masuda T, MSRI, 5(1), 28 (1999). 